\title{
Festas cívicas na Corte regencial $^{* 1}$
}

\section{Civic celebrations in the Rio de Janeiro Court during the Regency period}

\author{
MARCELLO OTÁVIO NERI DE CAMPOS BASILE \\ Doutor em História Social pela Universidade Federal do Rio de Janeiro \\ Professor do curso de Pós-Graduação Lato Sensu de \\ História do Brasil da Universidade Candido Mendes \\ Rua Almirante Cochrane, 240/302, Tijuca, RJ \\ marcellobasile@ig.com.br
}

\begin{abstract}
RESUMO Momento mais conturbado da história do Brasil, e também um dos mais ricos e singulares em termos de organização, discussão e participação políticas, o período regencial (1831-1840) foi igualmente marcado por intensas festividades cívicas. Tais manifestações - como o 25 de Março (juramento da Constituição), o 7 de Abril (abdicação de Pedro I), o 7 de Setembro (Independência) e o 2 de Dezembro (nascimento de Pedro II) — constituem o objeto deste trabalho. São analisados, assim, os rituais observados nessas festas, reveladores das intenções dos organizadores, bem como as tensões e os conflitos que evidenciavam os desvios de seus ideais. Ressalte-se ainda o papel que tiveram na mobilização dos mais diversos segmentos sociais, na afirmação dos valores nacionais e na legiti-
\end{abstract}

\footnotetext{
* Artigo recebido em 05/06/2005. Aprovado em 25/08/2005.

1 Este artigo é versão ligeiramente modificada do capítulo IV de minha tese de Doutorado, O Império em construção: projetos de Brasil e ação política na Corte regencial. Rio de Janeiro: PPGHIS - U.F.R.J., 2004.
} 
mação do poder monárquico. Jornais, panfletos e documentos da Câmara Municipal constituem as principais fontes de pesquisa.

Palavras-chave rituais cívicos, lutas políticas, identidade nacional

ABSTRACT The regency period (1831-1840) was the most turbulent in all of Brazil's history, as well as one of the richest in terms of political organization, mobilization and debate. It was marked too by vigorous civic celebrations. The object of this paper are these events - like the 25 March (oath to the Constitution), the 7 April (Pedro I's resignation), the 7 September (Brazilian independence) and the 2 December (Pedro ll's birthday). It first analyses the rituals of these celebrations, which reveal the intensions of the organizers, as well the tensions and conflicts that demonstrate deviations of their ideals. Secondly, it stress the civic rituals' role to mobilization of several social layers, to statement of national values and to legitimation of the monarchical power. The research sources are newspapers, pamphlets and City Council's documents.

Key words civic rituals, political struggles, national identity

Fase mais conturbada da história do Brasil, o período regencial é também um dos mais ricos e singulares em termos de organização, discussão e participação políticas. A grave crise resultante da oposição a Pedro I e, em seguida, da disputa pelo governo regencial, consoante com a vacância do Trono e a falta de unidade, até então, da elite política ${ }^{2}$ - privando a Regência de importantes mecanismos reguladores de conflito -, ensejaram a formação de três facções: os liberais moderados, liberais exaltados e caramurus, portadores de diferentes projetos políticos.

Situados ao centro do campo político imperial, os moderados seguiam os postulados clássicos liberais, tendo em Locke, Montesquieu, Guizot e Constant suas principais referências; pretendiam, e conseguiram, efetuar reformas político-institucionais que reduziam os poderes do imperador, davam maiores prerrogativas à Câmara dos Deputados e autonomia ao Judiciário, e garantiam a observância de direitos previstos na Constituição, almejando uma liberdade moderna que não ameaçasse a ordem imperial. À esquerda do campo, adeptos de um liberalismo radical de feição jacobinista, inspirado sobretudo em Rousseau, os exaltados buscavam conjugar princípios liberais clássicos e ideais democráticos, pleiteando profundas reformas políticas e

2 Sobre a ulterior homogeneidade da elite política imperial, cf CARVALHO, José Murilo de. A construção da ordem: a elite política imperial. Brasília: Editora da Universidade de Brasília, 1981. Introdução e capítulo 1. 
sociais, como uma república federativa, a extensão da cidadania política e civil a todos os segmentos sociais livres, o fim gradual da escravidão, uma relativa igualdade social e até um tipo de reforma agrária. À direita do campo, os caramurus filiavam-se à vertente conservadora do Liberalismo, tributária de Burke; críticos ferozes da Abdicação e avessos a qualquer reforma na Constituição — vistas como quebra arbitrária do pacto social —, defendiam uma monarquia constitucional fortemente centralizada, ao estilo do Primeiro Reinado, e, excepcionalmente, nutriam anseios restauradores. ${ }^{3}$

Em meio à crise, emergia na capital imperial uma incipiente, porém ativa, esfera pública, ${ }^{4}$ na qual se desenvolviam novos ou amplificados palcos de ação política, como a imprensa, as associações, as revoltas e as manifestações cívicas. É no interior dessas arenas que, para além dos círculos palacianos e das instituições representativas, travavam-se as lutas políticas, verificando-se uma politização das ruas, com a entrada em cena de novos atores políticos e de camadas sociais até então excluídas de participação ativa. Este artigo analisa, assim, as festas cívicas nacionais no Rio de Janeiro, as quais, a despeito da escassez de estudos para o Império, ${ }^{5}$ conheceram notável desenvolvimento durante a fase das regências trinas, impulsionadas pela efervescência política. ${ }^{6}$

3 Sobre os projetos moderados, exaltados e caramurus na Corte, BASILE, Marcello Otávio Neri de Campos. Ezequiel Corrêa dos Santos: um jacobino na Corte imperial. Rio de Janeiro: Fundação Getúlio Vargas, 2001; e MOREL, Marco. La formation de l'espace publique moderne a Rio de Janeiro (1820-1840): opinion, acteurs et sociabilité. Paris: U.F.R. d'Histoire - Université de Paris I (Pantheon Sorbonne), 1995. 2 vs, capítulo 3 (Tese de Doutorado).

4 Para o conceito de esfera pública, ver HABERMAS, Jürgen. Mudança estrutural da esfera pública: investigações quanto a uma categoria da sociedade burquesa. Rio de Janeiro: Tempo Brasileiro, 1984, sobretudo p. 42. Sobre a formação da esfera pública imperial, vide MOREL, Marco. La formation de l'espace publique moderne a Rio de Janeiro; NEVES, Lúcia Maria Bastos Pereira das. Corcundas e constitucionais: a cultura política da Independência (1820-1822). Rio de Janeiro: Revan / FAPERJ, 2003; e BASILE, Marcello Otávio Neri de Campos. Anarquistas, rusguentos e demagogos: os liberais exaltados e a formação da esfera pública na Corte imperial (1829-1834). Rio de Janeiro: PPGHIS - U.F.R.J., 2000. Capítulo VIII (Dissertação de Mestrado).

5 Vide os trabalhos de Hendrik Kraay (em andamento), que analisa as manifestações cívicas na Bahia e na Corte pós-Independência, sublinhando os rituais peculiares (nem sempre conforme as expectativas oficiais, mas denotando lealdade ao Estado) introduzidos pela intensa participação popular; de Carla Chamon, sobre as festas cívicas de Minas Gerais, realizadas em 1815 (criação da fábrica de ferro do Morro do Pilar, no arraial do Tejuco), 1831 (abdicação de Pedro I) e 1845 (fim da Farroupilha); e de lara Lins Souza, que, abordando os discursos, práticas políticas e representações simbólicas referentes ao poder monárquico no Brasil e, em particular, à construção da imagem pública de Pedro I, destaca o papel pedagógico das festas cívicas da realeza na configuração de uma liturgia política que valorizava o espaço público como forma de afirmação do poder real, da pessoa do imperador, do novo pacto social e de certa noção de ordem. Cf. KRAAY, Hendrik. Definindo nação e Estado: rituais cívicos na Bahia pós-Independência (1823-1850). Topoi: revista de História, Rio de Janeiro, no 3 setembro de 2001; KRAAY, Hendrik. Between Brazil and Bahia: celebrating Dois de Julho in nineteenth-century Salvador. Journal of Latin American Studies, Cambidge, n 31, 1999; KRAAY, Hendrik. Nation, State, and popular politics in Rio de Janeiro: civic rituals after Independence (mimeo.); KRAAY, Hendrik. Sete de Setembro: changing meanings of Independence celebrations in Rio de Janeiro, 1823-1864 (mimeo.); CHAMON, Carla Simone. Festejos imperiais: festas cívicas em Minas Gerais (1815-1845). Bragança Paulista: Editora da Universidade São Francisco, 2002 sobretudo capítulo 3; e SOUZA, lara Lis Franco Schiavinatto Carvalho. Pátria coroada: o Brasil como corpo político autônomo - 1780-1831. São Paulo: UNESP, 1999, em especial capítulo 5.

6 Segundo Kraay, até o fim de 1829 as festas cívicas do Primeiro Reinado tiveram pouco interesse na Corte, sendo marcadas por rituais estreitamente controlados de cima para baixo, nos quais havia pouco espaço para improvisos, para participação popular e para críticas ao governo. Foi somente a partir de 1830 que as festas cívicas fluminenses - impulsionadas pelo acirramento das lutas políticas e, em particular, pela ação radical dos exaltados - ganharam amplitude e contagiaram a Corte, transformando-se em palco importante das disputas políticas, em manifestações de oposição, não-controladas pelo governo e com notável envolvimento popular. Cf. KRAAY, Hendrik. Nation, State, and popular politics in Rio de Janeiro: civic rituals after Independence, p.8-9; KRAAY, Hendrik. Sete de Setembro: changing meanings of Independence celebrations in Rio de Janeiro, 1823-186, p.4-8. 


\section{Rituais e intenções: a ordem nas festas}

Detentores do poder regencial, mas cientes da importância estratégica das ruas na disputa política, os moderados faziam um tipo de uso do espaço público diferente do privilegiado pelos rivais. Ao invés de apelarem para ações contestatórias, preferiram mobilizar o fervor patriótico da população em manifestações cívicas que periodicamente celebravam eventos marcantes da história recente do Brasil independente. A seu modo, exaltados e caramurus também participavam ativamente - bem mais do que os moderados gostariam - dessas festas, mas eram estes últimos que as promoviam oficialmente (e não só por meio do governo). Buscavam, assim, controlar um espaço - as ruas - já ocupado pelos exaltados e logo disputado pelos caramurus, aproveitando a tradição herdada do período colonial de festejar aniversários, casamentos e ascensões da realeza. ${ }^{7}$

A 6 de outubro de 1831, entrou em debate Câmara dos Deputados - sendo aprovado no dia 10 e convertido em decreto a 25 do mesmo mês - o novo calendário cívico nacional da Regência, adequado à era que se iniciava. ${ }^{8}$ Saía o 12 de Outubro (nascimento e Aclamação de dom Pedro I como imperador do Brasil) e entrava o 2 de Dezembro (natalício de Pedro II) e 07 de Abril (Abdicação), mantendo-se o 25 de Março (juramento da Constituição), o 7 de Setembro (convencionado, desde 1823, como data da Independência), o 9 de Janeiro (dia do Fico) e o 3 de Maio (instalação da Assembléia Nacional Legislativa), fixados em 1826. ${ }^{9}$ Os mais comemorados ou concorridos na Corte foram os dois recém-instituídos e aqueles dois primeiros preservados.

Estas festas públicas eram marcadas por rituais pré-determinados e geralmente comuns a todas, que se estendiam ao longo do dia, reunindo autoridades civis, eclesiásticas e militares, além de grande concurso de pessoas provenientes das mais diversas camadas sociais. Começavam, pela manhã ou à tarde, com um desfile militar pomposo, em geral realizado no campo da Honra (atual campo de Santana) ou no largo do Paço (praça Quinze de Novembro), no qual sobressaíam os cidadãos milicianos da Guarda Nacional, passando em revista aos ministros, regentes e ao próprio imperador menino. Na "grande parada" de 2 de Dezembro de 1833, por exemplo, formaram-se legiões da Guarda Nacional e tropas de $1^{a}$ linha do Exército, "fardados todos com asseio, e luzimento; e passaram em conti-

7 Um amplo panorama das festividades públicas na Colônia encontra-se em JANCSO, Istvan, e KANTOR, Iris (org.). Festa: cultura \& sociabilidade na América portuguesa. 2 vs. São Paulo: Hucitec /EDUSP /FAPESP / Imprensa Oficial do Estado de São Paulo, 2001, sobretudo v.l - p.75-195 e v.ll - p.545-599.

8 Havia, no entanto, em respeito a particularidades regionais, alguns feriados cívicos locais, como o famoso 2 de Julho (expulsão das tropas portuguesas de Salvador, em 1823), na Bahia.

9 Annaes do Parlamento Brazileiro - Camara dos Srs. Deputados. Sessão de 1831. Coligidos por Antonio Pereira Pinto. Rio de Janeiro: Typographia de H. J. Pinto, 1878, t.2 , p.220 e 229. 
nência, na forma do costume", em tributo aos oito anos de Pedro II. ${ }^{10} \mathrm{Na}$ de 7 de Setembro do ano seguinte, a principal atração foi o Corpo de Artilharia da Guarda Nacional, "cujo entusiasmo cívico, e adiantamento no exercício da sua arma, correm parelha". ${ }^{11}$

Ainda de manhã ou à tarde (às vezes em ambas as ocasiões), realizava-se um solene Te Deum, geralmente na igreja de São Francisco de Paula ou na Capela Imperial (igreja de Nossa Senhora do Carmo). Neste último caso, a cerimônia, com convidados mais selecionados (altas autoridades e cortesãos), era promovida pelo governo; no primeiro, com assistência mais heterogênea (franqueada aos sócios da entidade e a cidadãos diversos, além de autoridades), pela Sociedade Defensora da Liberdade e Independência Nacional. A associação moderada era então a grande promotora das festas cívicas. Na celebração dos dez anos da Independência, "o Templo de S. Francisco de Paula, ricamente decorado, reuniu brilhante concurso de cidadãos, todos animados do mais vivo fervor pela independência do país. O Hino de graças foi elevado ao altíssimo". ${ }^{2}$ Já no nono aniversário do juramento da Constituição, mais de mil pessoas foram à igreja e ao largo de São Francisco de Paula, "e aí, como irmãos que um sentimento só reunia, simpatizavam na alegria dos semblantes, nas demonstrações do mais vivo patriotismo". ${ }^{13}$

Precedia a missa e o cântico de ação de graças um sermão cheio de exortações políticas. Ficou famoso o proferido por frei Francisco do Mont'Alverne na comemoração do 25 de Março, às vésperas da Abdicação e em meio à crise que sucedeu às Noites das Garrafadas. O discurso, feito na presença do imperador - que, todavia, não fora convidado para a cerimônia - denotava bem a posição dos moderados naquele momento; recheado de elogios à monarquia liberal e à Constituição jurada (isto é, sem as reformas pleiteadas pelos exaltados), mas também de críticas ao despotismo, apologias à liberdade e até de insinuações à legitimidade do direito de resistência:

É uma injustiça, reconhecer nas revoluções políticas dos povos a influência exclusiva das paixões (...) Folheando os Anais dos povos, consultando os monumentos, que atestam a passagem destas lavas, que têm engolido as Monarquias, e as mais florentes [sic] Repúblicas, a Filosofia assinala com segurança a causa destas comoções violentas (...)

(...) é fácil entrever nestas reações espantosas, e formidáveis a luta sublime da razão contra os abusos d'um Poder, que fazendo-se tirânico, e opressor tinha cessado d'encher seus fins importantes, e sublimes: não é difícil reconhecer a nobre expressão de vingança, com que os povos, cansados de suportar seu

10 Aurora Fluminense, $\mathrm{n}^{\circ} 850,6 / 12 / 1833$.

11 Aurora Fluminense, $n^{\circ}$ 954, 10/9/1834.

12 Aurora Fluminense, $n^{\circ} 673,10 / 9 / 1832$.

13 Aurora Fluminense, $n^{\circ} 750,27 / 3 / 1833$. 
aviltamento, fazem pedaços [sic] esses tronos (...) O Sábio tinha já dito, que as revoluções dos povos eram causadas por a perfídia, os ultrajes, as violências, e injustiça, que se lhes fazia [sic]..$^{14}$

Um ano depois, quando as reformas constitucionais já haviam passado na Câmara e aguardavam deliberação do Senado (que rejeitaria o chamado projeto Miranda Ribeiro), o sermão coube ao reverendo padre Manoel Alvares, que mostrou "as vantagens do sistema constitucional, e os benefícios que nos têm provindo de possuirmos a Lei fundamental jurada"; mas, apesar de ser membro da Defensora - que, mesmo sem muita convicção, apoiou as reformas - , pregou que o princípio federal consagrado na Constituição (na figura dos conselhos provinciais) era já "do mais transcendente liberalismo, e bastaria por si só para temperar muito a autoridade do Chefe da Nação", alertando ainda os brasileiros que "conheçam bem o que possuem e não queiram arriscá-lo, a troco de teorias que a experiência ainda não sancionou". ${ }^{15}$ No 7 de Abril de 1833, o orador voltou a ser Mont'Alverne, conhecido pelo domínio da oratória, que, "com aquela unção, calor, dicção brilhante, e eloqüência que distinguem os seus discursos sagrados", fez aplaudido sermão, no qual a "linguagem do patriotismo ardente se abraçou com os ditames da religião santa". ${ }^{16}$

Como em outros rituais públicos oficiais do Império, ${ }^{17}$ nota-se aqui a estreita imbricação entre Igreja e Estado, entre política e religião, que, à maneira do Antigo Regime, conferia caráter sagrado às festas cívicas, contribuindo para legitimá-las. O povo ou seus protagonistas viam-se, assim, forçados a compartilhar com Deus a responsabilidade e a glória pelos sucessos políticos; como o 7 de Abril, sobre o qual o padre, recém-eleito deputado, João Climaco de Alvarenga Rangel exortava os concidadãos a "render graças ao Deus, que abriu em nosso favor os primeiros tesouros da sua misericórdia para libertar-nos dos pesados ferros, que a tirania preparava". ${ }^{18}$

Os festejos prosseguiam à noite, com rituais variados. Não podia faltar a chamada luminária ou a/vorada, que produzia especial efeito visual nas ruas lúgubres da Corte (e de todo o Império), fracamente iluminadas por lampiões

14 MONTE ALVERNE, Francisco do. Oração d'Acção de Graças, que no dia 25 de março de 1831 anniverario do solemne juramento da Constituição, celebrado na igreja de S. Francisco de Paula, por O Povo Fluminense, recitou Fr. Francisco do Monte Alverne, Pregador de S. M. I. Rio de Janeiro: Typographia de R. Ogier, 1831, p.7 e 8.

15 Aurora Fluminense, $n^{\circ} 610,28 / 3 / 1832$

16 Aurora Fluminense, $n^{\circ} 755,10 / 4 / 1833$

17 Bem parecido é o caso das eleições, cuja votação era precedida por sermão, missa e Te Deum. O próprio Mont'Alverne especializou-se neste tipo de pregação, que, em suas palavras, visava definir aos eleitores a "linha de conduta, que deveis seguir no desempenho dos deveres". MOMTE-ALVERNE, Francisco do. Discurso, que, na reunião do Collegio Eleitoral do Rio de Janeiro, para proceder-se á eleição d'hum senador por esta provincia recitou na Capella Imperial, em o dia 28 de maio de 1833 fr. Francisco do Momte-Alverne pregador de S. M. o Imperador. Rio de Janeiro: Typographia Americana de I. P. da Costa, 1833, p.4. Cf. GRAHAM, Richard. Clientelismo e política no Brasil do século XIX. Rio de Janeiro: Editora da U.F.R.J., 1997, p.93-94 e 156-157.

18 RANGEL, J. C. A. [João Climaco Alvarenga Rangel]. Discurso recitado no Te Deum, que pelo aniversario da Regeneração politica do Brasil, solemnisarão os patriotas da villa de Iguassú. Rio de Janeiro: Typographia Commercia de P. Gueffier, 1834, p.16 
à base de azeite de peixe (óleo de baleia). Às vésperas de cada evento, um edital da Câmara Municipal convidava toda a população a iluminar a frente das casas nas noites festivas, "em demonstração de regozijo público", e a ornar as janelas com cortinas nas ruas percorridas pelo cortejo imperial. ${ }^{19} \mathrm{As}$ luminárias constituíam espetáculos sortidos e de distinção social, em que, conforme os recursos e interesses de cada um, colocavam-se nas portas e janelas desde simples velas de cera e lamparinas de barro, até sofisticadas lanternas de folha de flandres e vidro, transparências e painéis coloridos pintados com dísticos patrióticos. Havia ainda a iluminação especial feita para os prédios públicos e logradouros mais importantes, que se tornavam um grande evento social, atraindo elevado número de espectadores. Como a que teve lugar na Villa Real da Praia Grande (Niterói), no 7 de Abril de 1831, que manteve a atenção do público até às duas horas e meia da madrugada, em meio a vivas proclamados e poesias recitadas..$^{20}$ Ou a do 7 de Setembro do ano seguinte, no Passeio Público, assistida por milhares de homens e mulheres de todas as classes, inclusive o imperador, os regentes e os ministros, com direito a uma banda de música executando sinfonias; o evento foi custeado, não pelo governo, mas por uma associação de cidadãos patriotas, reunida por Antonio Ribeiro Fernandes Torbes. ${ }^{21}$

A politização das ruas neste período propiciava momentos de revolta, de luta por direitos ou mudanças, mas também de júbilo em torno da causa pública, canalizados nesses festejos. Vale lembrar o testemunho do mineiro Francisco de Paula Rezende, que vivera sua infância durante a Regência e em cuja memória ficara bem gravada a efervescência política daquela época:

(...) nesse tempo o Brasil vivia, por assim dizer, muito mais na praça pública do que mesmo no lar doméstico; ou, em outros termos, vivia em uma atmosfera tão essencialmente política que o menino, que em casa muito depressa aprendia a falar liberdade e pátria, quando ia para a escola, apenas sabia soletrar a doutrina cristã, começava logo a ler e aprender a constituição política do império.

Daqui resultava que não só o cidadão extremamente se interessava por tudo quanto dizia respeito à vida pública; mas que não se apresentava um motivo, por mais insignificante que fosse, de regozijo nacional ou político, que imediatamente todos não se comovessem, ou que desde logo não se tratasse de cantar um TeDeum mais ou menos solene e ao qual todos, homens e mulheres, não deixavam

19 LEGISLATIVO MUNICIPAL. Editaes Camara Municipal. 1830-1842. A. G. C. R. J. Códice nº 16-4-24 (p.130v,142, $144,156 v$ ). A convocação era feita também quando ocorriam atos políticos relevantes, como a aprovação do Ato Adicional ou as posses dos regentes Feijó e Araujo Lima (p.72, 92v, 93 e 142).

20 Cf. O Brazil Afflicto, $n^{\circ} 1,20 / 4 / 1833$

21 FESTEJOS PELA DATA DA INDEPENDENCIA NACIONAL. Varios papeis sobre a commemoração da data de Sete de Setembro - anniversaria da Independencia Nacional. 1834, 1856 a 1859, 1867, 1870 e 1871. A. G. C. R. J. Códice n 43-3-64 (Requerimento de Antonio Ribeiro Fernandes Torbes à Câmara Municipal, p. 1). Relatos do evento constam em Aurora Fluminense, no 954, 10/9/1834; e Jornal do Commercio, 9/9/1834. 
de ir assistir; ou que não fosse isto ocasião para que à noite, pelo menos, se tratasse de pôr na rua uma bonita alvorada, mais ou menos estrondosa. ${ }^{22}$

As noites festivas da Regência eram iluminadas e coloridas também por espetáculos pirotécnicos e embaladas por músicas e danças, geralmente promovidos por particulares. Diversos requerimentos neste sentido eram encaminhados à Câmara Municipal, incumbida do controle das festas e diversões públicas. ${ }^{23}$ Pouco antes das Garrafadas, moradores da rua da Quitanda (reduto de portugueses e palco central do conflito), "Cidadãos amantes do Governo Constitucional, e da Nação Brasileira", pediram, e obtiveram, licença para "projetando colocar fogo preso na mesma Rua", nas comemorações do 25 de Março, garantindo não ofender "a Moral, ou a tranqüilidade pública". ${ }^{24}$ Já Joaquim da Silva Ramos (que parecia ser semi-analfabeto, dada a péssima redação da petição) não foi autorizado a representar, no centro da cidade, uma dança da China ensaiada para os onze anos da Independência, apesar da promessa de apresentá-la "com a maior satisfação e zelo e decência Própia [sic] sem dar a mais pequena esconduta [sic] ao respeitável público". ${ }^{25}$ Ainda em 1833, no 7 de Abril, as raízes indígenas da nacionalidade brasileira foram evocadas por pessoas em trajes nativos, que, em diversas ruas, "executaram danças apropriados [sic] ao caráter do povo que representavam"; e, desde o dia anterior, o quartel do Corpo de Guardas Municipais Permanentes vinha sendo palco de "bailes graciosos" oferecidos à mocidade. ${ }^{26}$ Os mesmos setores do Povo e Tropa que apareciam unidos nas revoltas, confraternizavam-se em ocasiões festivas. ${ }^{27}$ Não faltavam também festas particulares, ${ }^{28}$ como bailes e jantares em casas distintas da sociedade, bem como oferecimento de mesas de doces e refrescos a vizinhos e transeuntes. Em 1833, alguns

22 REZENDE, Francisco de Paula Ferreira de. Minhas recordações. $2^{a}$ ed. Belo Horizonte: Itatiaia /São Paulo: EDUSP, 1988, p.53-54. Tamanho era o fervor cívico que o Jornal do Commercio, n² 20, 26/9/1831, anunciava a venda da Bibliotheca Constitucional do Cidadão Brasileiro, em sete volumes, ao preço de $1 \$ 360$ réis; e que o Laço Nacional Brasileiro, recém-regulamentado, também já estava à venda (Jornal do Commercio, nº 34, 12/10/1831).

23 Martha Abreu constatou o crescimento, exatamente na década de 1830, das medidas municipais que procuravam regular ou cercear as festividades. ABREU, Martha. O Império do Divino: festas religiosas e cultura popular no Rio de Janeiro, 1830-1900. Rio de Janeiro: Nova Fronteira / São Paulo: FAPESP, 1999, p.196-197.

24 FESTEJOS PELA DATA DO JURAMENTO DA CONSTITUIÇÃO DO IMPERIO (25/3/1824). Requerimento dos moradores da rua da Quitanda. 1831.2 p. A. G. C. R. J. Códice n 43-3-63.

25 FESTEJOS PELA DATA ANIVERSARIA DA INDEPENDENCIA NACIONAL 1833. $2 \mathrm{p}$. A G G C R J J Códice n 43-3-66. O auge dessas iniciativas foi por conta dos FESTEJOS DA CORÔAÇÃO E SAGRAÇÃO DO IMPERADOR. Contas de varios negociantes pela armação construida e cortinas com que se ornaram as janellas do Paço Municipal, para os nove dias de festejos. 1841. 4 docs. 5 p. Códice $n^{\circ} 43-3-67$

26 O Sete d'Abril, n $31,13 / 4 / 1833$.

27 No 25 de Março de 1831, por exemplo, após a cerimônia religiosa, um grupo de exaltados, liderado por Borges da Fonseca e Muniz Barreto, foi ver a iluminação especial feita para a ocasião dos quartéis do $1^{\circ}$ e do $2^{\circ}$ Corpo de Artilharia de Posição do Exército, comandados pelo brigadeiro Francisco de Paula Vasconcellos e pelo coronel Bittencourt. Foram todos convidados para um bródio preparado pela oficialidade, e lá ficaram até às duas horas da madrugada, divertindo-se com as poesias improvisadas por Barreto. No final, ambos foram levados em casa pelos militares, para protegê-los de um eventual encontro com portugueses. O Republico, n $51,30 / 3 / 1831$.

28 Cf. O Independente, n 72, 11/4/1832; Jornal do Commercio, 9/9/1831. 
"moços patriotas" organizaram um "modesto, mas decoroso baile" em louvor à Independência. ${ }^{29}$

A Sociedade Defensora exercia importante papel nos festejos noturnos. Desde o primeiro após a sua criação, o 7 de Setembro de 1831, promovia subscrições para financiar as cerimônias. Em sua estréia, limitou-se ao Te Deum da igreja de São Francisco de Paula, diante de mais de duzentos guardas municipais postados no largo, possuídos do "mais vivo patriotismo, e cordial afeição à ordem e à liberdade". ${ }^{30}$ Para tanto, arrecadou bem mais do que o necessário, segundo o relatório financeiro de 7 de dezembro deste ano: 3:639\$000 réis, gastando apenas 828\$000 rs., ficando em caixa 2:975\$640 rs. ${ }^{31}$ No ano seguinte, o 25 de Março foi celebrado da mesma forma pela entidade. ${ }^{32}$ Mas no primeiro aniversário do 7 de Abril houve, além do Te Deum, grande festa para sócios e familiares, na casa da Secretaria de Guerra, no campo da Honra, cuja frente foi tomada por uma multidão de curiosos, entretida por coreto de música militar. Com a presença de mais de quatrocentas pessoas, incluindo pelo menos sessenta senhoras, a reunião foi aberta com "eloqüente e entusiástica" oração, proferida pelo redator d'O Independente, Francisco de Salles Torres Homem, seguida do Hino do 7 de Abril, cantado por Domingos Alves Pinto e algumas senhoras, e da oferta de um ramo de honra ao sócio, e ministro da Guerra, Manoel da Fonseca Lima, "pelos serviços que prestou para a revolução gloriosa"; depois começaram as danças, que só terminaram às quatro horas e meia da madrugada, entremeadas por discurso improvisado de Evaristo da Veiga, por diversos vivas e por mais uma entoação do hino, tudo fartamente regado a refrescos e doces. ${ }^{33}$ Desta vez, conforme o relatório financeiro de $1^{\circ}$ de maio, as despesas foram bem mais elevadas: 1:194\$640 réis com as cerimônias religiosas de 25 de Março e 7 de Abril, e 2:028\$780 réis com a festa noturna, totalizando 3:223 $\$ 420$ réis; como era grande o dinheiro em caixa (que, com os $10 \$ 000$ réis recebidos depois, chegou a 2:985\$640 rs.), não se fez subscrição, gerando pequeno déficit de $237 \$ 780$ rs., que demorou, porém, a ser coberto pela associação. ${ }^{34}$

Ainda em 1832, por proposta de Evaristo na sessão de 12 de agosto, a Defensora festejou o 7 de Setembro apenas com a cerimônia religiosa; ${ }^{35}$

29 Aurora Fluminense, no $814,11 / 9 / 1833$

30 O Independente, n 38, 9/9/1831. Ver também Aurora Fluminense, n 526, 5/9/1831.

31 O Homem e a America, n $12,5 / 1 / 1832$.

32 Cf. Aurora Fluminense, $n^{\circ} 610,28 / 3 / 1832$

33 Aurora Fluminense, $\mathrm{n}^{\circ} 615,11 / 4 / 1832$. O Independente, $\mathrm{n}^{\circ} 72,11 / 4 / 1832$ notou quase duzentos sócios presentes. A letra do hino era do desembargador Ovídio Saraiva de Carvalho e Silva, a música, de Francisco Manoel da Silva.

34 O Homem e a America, $n^{\circ}$ 39, 18/8/1832. Em carta datada de 27 de julho de 1832, dirigida ao Conselho da Defensora, Jacinta Maria da Conceição reclamava o pagamento dos doces a ela encomendados para a festa de 7 de Abril (O Homem e a America, $\mathrm{n}^{\circ}$ 40, 25/8/1832).

35 O Homem e a America, n $40,25 / 8 / 1832$.

\section{2}


é que os moderados nada tinham então a comemorar, com a subida ao poder, após o fracassado golpe de Estado de Feijó, de um ministério de oposição, o de Hollanda Cavalcanti. Mas, com a rápida queda do gabinete, logo depois do aniversário da Independência, a Defensora sentiu-se animada a celebrar os sete anos do monarca. A proposta inicial, bem ao estilo filantrópico, partiu também de Evaristo, na sessão de 25 de outubro, sugerindo, primeiro, que vinte meninos pobres fossem vestidos à custa da Sociedade e levados por uma comissão até Pedro II, a quem entregariam uma coroa de flores, e um deles faria discurso; segundo, que fosse feita uma subscrição e se rateasse a quantia obtida entre os meninos, à guisa de esmola. A proposta não foi aprovada, assim como a de Mont'Alverne, de enviar uma deputação de doze meninos escolhidos entre as famílias mais abastadas dos sócios. Prevaleceram, na sessão de 4 de novembro, as indicações de Barboza da Silva, para que apenas o presidente e os secretários fozessem os votos de felicitação da Sociedade, e do próprio Evaristo, sugerindo que cada membro efetivo e suplente do Conselho promovesse uma subscrição, a ser oferecida em 2 de Dezembro, para "atos de beneficência". ${ }^{66}$ Três semanas depois, foram contabilizados 1:452\$000 réis entre os conselheiros presentes, e se acatou a indicação de José Joaquim Borges para que a quantia fosse empregada em apólices de fundos públicos; estas seriam entregues, naquela data, ao Seminário de S. Joaquim, para que o rendimento fosse aplicado à manutenção dos meninos órfãos ali existentes, colocando-se pequena placa na sala principal desta instituição, registrando o ato. ${ }^{37}$ Por outro lado, o aniversário da Constituição, em 1833, não mereceu mais do que o tradicional ritual de sermão (proferido pelo cônego Januario da Cunha Barboza), missa e Te Deum;38 pois, se a data já causara constrangimento aos moderados no ano anterior, neste perdera grande parte do significado simbólico dos últimos tempos - o de defesa da inviolabilidade da Constituição - , com a aceitação pelo Senado da lei que definiu as bases da reforma. Mas o 7 de Abril foi comemorado, após a cerimônia religiosa, com grande baile no campo da Honra, que se prolongou até às quatro horas da manhã; mais de quinhentas pessoas de ambos os sexos foram ali entretidas com doces e refrescos em profusão, danças, músicas, recitais do hino consagrado àquele dia - cantado por algumas senhoras - e de várias poesias (uma delas, muito aplaudida, dizia ao final: "Saiba o filho reinar, que o pai não soube"; outra, uma Ode pindárica, era de autoria do ainda desconhecido Gonçalves de Magalhães). Alunos da Faculdade de Medicina homenagearam Evaristo da Veiga, oferecendo-lhe

\footnotetext{
36 O Homem e a America, no 47, 1/2/1833 e no 48, 9/2/1833.

37 O Homem e a America, $n^{\circ} 50,23 / 2 / 1833$. A quantia doada foi 1:6000\$000 réis ( $O$ Independente, $n^{\circ} 131$, 29/11/1832).

38 Aurora Fluminense, $n^{\circ} 750,27 / 3 / 1833$.
} 
uma coroa cívica; tudo acompanhado, com "patriótico entusiasmo", de vivas legais, puxados pelo presidente da associação, e diante do retrato reverenciado de Pedro II. 39

Prática bastante difundida nas festas cívicas de todo o Império, ${ }^{40}$ levando simbolicamente o monarca aonde sua presença física não era possível —, o ritual de veneração à sua imagem oficial retratada em pinturas — tratada como se fosse o próprio - fazia-se notar mesmo na Corte, dada a inconveniência de comparecer aos vários eventos festivos. Aproveitava-se, assim, para patentear a lealdade ao imperador, personificando a monarquia brasileira, e o próprio país, em sua pessoa.

$\mathrm{O}$ auge do requinte das festas da Defensora foi no aniversário de três anos da Abdicação. Os moderados comemoravam então a vitória sobre os caramurus, no final de 1833, e a anulação dos exaltados na Corte, e já contavam (dada a composição política da nova legislatura) com a certeza da passagem do Ato Adicional. Remontando a um movimento que apregoavam como obra exclusivamente sua, o 7 de Abril de 1834 era o momento ideal para celebrar este triunfo. A Sociedade organizou, assim, uma "reunião festiva" naquela noite, cujo programa era o seguinte:

O entretenimento principiará às 8 horas e $1 / 2$ da noite; menos no caso de ir S. M. I. honrar aquele ato; que então deverá começar, logo que S. M. I. chegue.

Terá primeiramente lugar uma boa Ouverture, ou Sinfonia; imediatamente o Hino, findo o qual, dará o Presidente da Sociedade os — Vivas.

Seguir-se-á tudo o que houver de cantoria, que nunca deverá exceder das 11 horas da noite. Terminada a cantoria, começarão as contradanças, em cujo intervalo poderão recitar-se Discursos, ou Poesias análogas ao objeto desta reunião; mas nunca, mais de uma Peça em cada intervalo.

O Presidente da Sociedade, de acordo com os Mestres-salas, é incumbido de toda a direção do festejo, entrada, e distribuição dos refrescos, doces \&c., sem que alguma outra pessoa possa ingerir-se nesses objetos.

Os Introdutores têm a seu cargo receber as Senhoras à porta exterior da Casa da Reunião, e trazê-las até à porta da Sala do Baile, em que deverão entregá-las às Senhoras encarregadas de fazer as honras da Casa.

Não se consentirá aos homens o trânsito, pelo lugar onde estiver o toucador das Senhoras, as quais serão aí conduzidas unicamente pelas Senhoras encarregadas de fazer as honras da Casa.

Não se consentirá que os homens se coloquem na Sala do Baile, de maneira que privem as Senhoras da vista do Espetáculo.

Qualquer indivíduo que sem ser Sócio, for encontrado na Sala do Baile, será mandado sair da Casa por ordem do Presidente da Sociedade.

Qualquer Sócio que, depois de admoestado, reiterar a prática de algum ato

39 Aurora Fluminense, no 755, 10/4/1833. Para a Ode pindárica e a coroa cívica, O Independente, no 162, 10/4/1833

40 Cf. SOUZA, lara Lis Franco S. C. Pátria coroada: o Brasil como corpo político autônomo, capítulo 5, p.260-263; KRAAY, Hendrik. Definindo nação e Estado: rituais cívicos na Bahia pós-Independência (1823-1850), p.70-71; SCHWARCZ, Lilia Moritz. As barbas do imperador: d. Pedro II, um monarca nos trópicos. São Paulo: Companhia das Letras, 1998, p.254-255. 
menos decoroso (o que não é de esperar) será igualmente mandado sair da Casa por ordem do Presidente da Sociedade. ${ }^{41}$

Foi a maior festa produzida pela Defensora, comparada pelos presentes a das grandes cortes européias. Compareceram mais de setecentos homens - sócios, autoridades, diplomatas e oficiais de Marinha estrangeiros -, além de quase cento e cinqüenta senhoras. Tudo saiu conforme planejado: o serviço, as luminárias, músicas, danças, cantos, recitais de poesias e hinos, discursos e vivas. Para coroar a festa, não faltaram sequer o imperador e suas irmãs (já sob a tutoria do marquês de Itanhaém, membro da entidade), que chegaram na hora marcada e até se dignaram a romper o baile, dançando gavota. Ao entrarem, após a abertura feita pela orquestra, o presidente da Sociedade, João Silveira do Pillar, dirigiu-lhes um discurso. Nele ressaltou que a Defensora, com este ato, "dá uma prova não equívoca do quanto se interessa na Exaltação de V. M. I. ao Trono do Brasil", e que a presença do imperador e de suas irmãs "é o melhor desmentido, que a Sociedade Defensora pode dar às intrigas daqueles, que incutiam falsos terrores com uma Associação, que tem sustentado, e há de sustentar, os Direitos da Nação, e os do nosso primeiro Monarca nascido na Terra de Santa Cruz". A função só terminou às quatro horas da manhã ${ }^{42}$

Espetáculos teatrais de gala eram também encenados especialmente nessas ocasiões. As peças, sempre concorridas, não raro contando com presença do imperador e dos regentes, eram realizadas no principal teatro da cidade, o Constitucional Fluminense; ${ }^{43}$ outras, no Theatrinho da Rua dos Arcos, mantido pela sociedade homônima. Devendo ser o teatro uma escola de moral e de virtudes, dotada de papel civilizador, as peças então encenadas revestiam-se de uma acentuada pedagogia política. Dramas como $O$ dia de júbilo para os amantes da liberdade, do dramaturgo lusitano Camilo José de Soares Guedes, representado no 3 de Maio de 1831, e O descobrimento do Brasil ou o vaticínio da Independência, composto em versos para o 7 de Setembro de 1837, criticavam o despotismo e exaltavam o patriotismo, a liberdade, o constitucionalismo e, muitas vezes, a monarquia. Grande parte das peças tinha origem européia, principalmente portuguesa e francesa, mas as idéias abstratas e genéricas que continham, independentemente do contexto original, favoreciam interpretações diversas e analogias arbitrárias acerca do passado recente e do momento vivido na Corte. Nesses espetáculos, tal como desde fins do Antigo Regime europeu, ${ }^{44}$

41 O Sete d'Abril, no 132, 29/3/1834

42 Aurora Fluminense, no 896, 11/4/1834

43 Era o Teatro São Pedro de Alcantara, que, em sintonia com os novos tempos da Regência, passou a se chamar Constitucional Fluminense logo após a Abdicação, voltando ao antigo nome depois da Maioridade. Atualmente, é o Teatro João Caetano, na praça Tiradentes.

44 Cf. SENNETT, Richard. O declínio do homem público: as tiranias da intimidade. São Paulo: Companhia das Letras, 1988, p.98-107. 
havia estreita interação entre atores e platéia. Esta não agia como mera espectadora passiva, mas participava ativa e exacerbadamente, fazendo críticas e elogios aos atores, mandando repetir cenas, passando o ponto das falas, interpretando o sentido dos textos, sugerindo novos desfechos, gritando, xingando, cuspindo; acrescentem-se a isso as freqüentes, e muitas vezes nada amistosas, interlocuções entre os próprios espectadores. ${ }^{45}$ Há de se notar ainda que faziam parte desses espetáculos (antes ou depois da encenação) o canto de hinos patrióticos e a recitação de poesias cívicas — ambos distribuídos em folhas volantes manuscritas, aparecendo muitas vezes depois na imprensa - além dos inevitáveis vivas, tornando-os verdadeiros momentos de catarse política. ${ }^{46}$

Hinos, poesias e vivas eram bastante difundidos em todos os rituais cívicos. Jornais e panfletos publicavam os dois primeiros. Alguns eram anônimos, como o Hymno offerecido á Briosa Nação Brasileira por occasião do dia 7 de Abril de 1831, cujo refrão dizia: "Exultai, que a Pátria exulta, / Ó Brasileira Nação! / Não enluta a escravidão / Da Liberdade o Altar". ${ }^{47}$ A maioria dos autores, porém, sentia-se envaidecida de assinar as obras. Um dos mais atuantes era o jovem Francisco de Paula Brito, que dedicou vários hinos e sonetos a tais ocasiões. Recorrentes eram os temas da libertação face ao jugo da escravidão política, do combate à tirania, do dever de morrer pela salvação da pátria, do heróico patriotismo brasileiro, da união do povo, do respeito à Constituição, da lealdade à monarquia sob Pedro II, do destino grandioso da nação; como nos versos recitados por Paula Brito no Teatro Constitucional Fluminense, a 7 de setembro de 1831:

[...] Sim, o Povo Brasileiro

Preza a Lei, preza o razão [sic],

Adora a Constituição,

Como seu Ídolo primeiro.

Só detesta o cativeiro,

A quem jura fazer guerra.

Quem das Santas Leis aberra,

Quer nossa reincidência,

E pra bem da Independência

Corra o sangue pela terra.
[...] Temos estrita união; Saiba o tirano Mandão, Que um Povo livre não [se] pisa,

Quando ele tem por divisa

Morrer livre, escravo não.

Rebente embora o vulcão

Estoure a mina da guerra

Corra o sangue pela terra

Morrer livre, escravo não. ${ }^{48}$

45 Ciente de toda a comoção causada por tais peças, o cômico luso José Joaquim de Barros, incumbido de representar o tirano em O dia de júbilo, logo esclareceu na imprensa que só aceitara fazer o papel em benefício do drama, mas que seus sentimentos eram inteiramente contrários aos do personagem. Cf. SOUZA, Silvia Cristina Martins de. As noites do Ginásio: teatro e tensões culturais na Corte (1832-1868). Campinas: Editora da UNICAMP, 2002, p.31. Ver Jornal do Commercio, 6/9/1837

46 Para essas celebrações, ver, por exemplo, Aurora Fluminense, $\mathrm{n}^{\circ}$ 814, 11/9/1833 e n 850, 6/12/1833; e O Sete d'Abril, n 140, 29/4/1834 e n 378, 10/9/1836

47 ANÔNIMO. Hymno offerecido á briosa Nação Brasileira por occasião do dia 7 de Abril de 1831. [Rio de Janeiro]: Typographia de Thomas B. Hunt e C., s/d. 1 p.

48 O Exaltado, n 8, 29/9/1831. Do autor ver também BRITO, Francisco de Paula. Hymno offerecido á Mocidade Brasileira, no dia 25 de Março de 1831. Rio de Janeiro: Typographia Imperial de E. Seignot-Plancher, s/d.; [IDEM]. Hymno ao dia 25 de Março, anniversario do juramento da Constituição. Offerecido ás Senhoras Brazileiras. Assinada 
Já os vivas - palavras de ordem que expressavam lealdades políticas - eram em geral puxados por alguém preeminente na multidão, que os repetia entusiasticamente. Os mais comuns conclamavam o objeto celebrado, qualificado por um adjetivo peculiar: a sagrada Constituição, o g/orioso 7 de Abril, a majestosa Independência, o imperador constitucional, além de outros, por exemplo, votados à santa religião, à pátria, à liberdade, à Regência, aos representantes da nação e ao povo. A ordem em que eram dados os vivas denotava a hierarquia de valores de quem os proclamava e a conveniência de cada circunstância, assim como a omissão de algum desses vivas, a não-repetição pelo público ou outro dado em resposta eram indicadores políticos importantes.

Do ponto de vista das intenções políticas, as festas cívicas regenciais, com seus rituais diversos e seu potencial mobilizador de sentimentos e indivíduos, eram, portanto, instrumentos de pedagogia política, utilizados pelo governo e seus partidários — os moderados - para legitimar o poder monárquico, fomentar os laços de união e de comunhão em torno da nação, conquistar a adesão da população e cultivar as virtudes cívicas nos limites da ordem celebrada.

Tais mensagens eram difundidas tanto nas festas, como nos relatos da imprensa. Ao noticiar os preparativos para o aniversário de nove anos da Independência, a Aurora Fluminense assinalava que o "7 de Setembro é o dia dos Brasileiros; nele pela primeira vez se escutou o grito da independência da pátria, e nos subtraímos ao jugo da antiga metrópole"; assim, fazia votos para que neste dia "todos os corações se congraçassem; e que todos os Brasileiros que amam a pátria (sejam aliás quais forem os seus princípios políticos) escolhessem o 7 de Setembro para se abraçarem irmamente". ${ }^{49}$ Já o 7 de Abril era lembrado por O Independente, no seu primeiro aniversário, como o dia em que se operou "a nossa segunda regeneração política, não à maneira das outras revoluções, que a história nos apresenta escritas em caracteres de sangue; mas sim pela moderação, por império da razão e de uma civilização ilustrada"; por isso, o "mais brilhante dos nossos acontecimentos políticos" devia ser recordado e celebrado pela "grande família Brasileira" com um "tom uniforme". ${ }^{50}$ Já o 25 de Março solenizava o "Símbolo de nossa união, no meio dos partidos", pois a Constituição brasileira "encerra em si quanto é preciso para fazer efetiva a liberdade da população: não há direito, não há dever social que ali não esteja consignado", contemplando igual e invariavelmente o fraco e o forte, o exagerado e o retrógrado. ${ }^{51} \mathrm{E}$, de modo semelhante, o 2 de Dezembro festejava o "penhor da unidade do Brasil,

\footnotetext{
"Pela Redactora da Mulher do Simplicio". Rio de Janeiro: Typographia Imparcial de Brito, s/d.; IDEM. Hymno ao Memoravel Dia 7 d'Abril de 1831. Rio de Janeiro: Typographia d'E. Seignot-Plancher, 1831.

49 Aurora Fluminense, no $526,5 / 9 / 1831$

50 O Independente, $\mathrm{n}^{\circ} 71,7 / 4 / 1832$.

51 Aurora Fluminense, $n^{\circ} 610,28 / 3 / 1832$
} 
talvez de sua existência como Nação". 52 Em torno dos ideais propagados de unidade, harmonia e consenso, simbolizados nos objetos de veneração cívica - a Independência, a Abdicação, a Constituição e o imperador —, construía-se uma memória nacional, que seria largamente reforçada no Segundo Reinado. Pois "É assim que atravessam os tempos solenemente recordados pelos filhos da pátria esses acontecimentos extraordinários, que marcam as épocas nos anais das nações". ${ }^{3}$

\section{Desvios e tensões: a desordem nas festas}

Nem tudo, porém, era festa. Tamanhas eram as divisões políticas e tantos eram os meios e a freqüência com que estas ocorriam, que os festejos regenciais não poderiam ficar imunes às rivalidades e aos conflitos. ${ }^{54} \mathrm{O}$ problema começava já com os próprios homenageados. Todos eles suscitavam contrariedades ou constrangimentos, conforme o caso, em cada uma das três facções. A Constituição jurada passou a representar, para além da bandeira do constitucionalismo, a oposição às reformas, identificando-se aos caramurus; assim, não empolgava os exaltados, defensores de amplas mudanças constitucionais (e até da elaboração de nova Carta), ao mesmo tempo em que causava sério desconforto nos moderados, que não conseguiam equacionar bem seus princípios anti-reformistas e sua posição estratégica favorável às mudanças. A Abdicação - promovida por moderados e exaltados - era objeto de eterno lamento para os caramurus, saudosos dos tempos de Pedro I; e de ressentimento ou até de arrependimento para alguns exaltados, excluídos do poder. O próprio Pedro II não tinha muito valor para os republicanos exaltados mais convictos e nem para os restauradores caramurus mais decididos. Até mesmo a Independência - personalizada nas figuras de Pedro I e do caramuru José Bonifacio — tornara-se controversa, trazendo inconveniências para moderados e exaltados. Nenhum desses quatro temas, portanto, congregava plenamente as três facções políticas da Corte. E o fato de uma delas assumir a organização oficial dos festejos adicionava uma carga maior de rivalidade e descontentamento, fazendo com que eles ficassem bem distantes de seus ideais de união, harmonia e consenso.

Não por acaso, os dias que antecediam e em que ocorriam esses eventos eram geralmente marcados por clima de tensão e incerteza. Foi assim já na primeira grande celebração ocorrida sob os auspícios da Regência, o

52 Aurora Fluminense, no 850, 6/12/1833.

53 O Independente, $\mathrm{n}^{\circ} 71,7 / 4 / 1832$.

54 Kraay e Chamon também verificaram manifestações turbulentas e desviantes nas festas cívicas da Bahia e de Minas Gerais neste mesmo período. Cf. KRAAY, Hendrik. Between Brazil and Bahia: celebrating Dois de Julho in nineteenth-century Salvador, p.264-274; KRAAY, Hendrik. Definindo nação e Estado: rituais cívicos na Bahia pós-Independência (1823-1850), p.73-77; e CHAMON, Carla Simone. Festejos imperiais: festas cívicas em Minas Gerais (1815-1845), capítulo 4. 
7 de Setembro. Quatro dias antes, teve início uma intensa polêmica acerca de boatos aterradores que previam para aquela data uma sangrenta rusga promovida pelos exaltados visando derrubar o governo. ${ }^{55}$ No dia da festa, malgrado o desassossego da população e a paralisação do comércio, ${ }^{56}$ houve apenas um tumulto no Teatro Constitucional Fluminense. Começou ainda durante o espetáculo, com as habituais intervenções da platéia para os atores, "abuso que se vai introduzindo muito", tornando o palco uma "escola de indecência em vez de escola de moral". O conteúdo da peça, também como de hábito, favorecia essas manifestações:

(...) a peça que foi à cena tem um excelente diálogo entre dois soldados, aonde se acham algumas proposições genéricas de eterna verdade, e da melhor moral; essas mereceram muitas palmas aos tais indivíduos, porque, por isso mesmo que são genéricas, cada um as aplicava às suas opiniões; mas quando um soldado diz — se são criminosos, as leis que os castiguem — quando se diz mais — logo que se não respeitam as leis, logo que se ataca a ordem estabelecida, o edifício social se despedaça \&c. - aí não acharam motivos de aplausos, porque essa doutrina não Ihes convém.

A agitação era promovida por um grupo de exaltados, que costumavam freqüentar o teatro. Por isso dizia a Astréa que o "Termômetro onde se pode regular o sossego, que há de haver em qualquer noite no Teatro é o número de moços de chapéu de palha, e fita preta, que se apresentam na platéia, e que se dizem os patriotas por excelência". ${ }^{57}$ Ao terminar o espetáculo, romperam diferentes gritos de vivas e de morras, e grande correria no saguão e na saída do teatro, terminando com insultos a vários jovens que usavam uniformes da Guarda Municipal. ${ }^{58}$

Por conta de confusões como essa, a Câmara Municipal já estabelecera uma postura (em 21 de julho de 1831), providenciando sobre a revisão das peças a serem encenadas, e, a 22 de novembro, baixou edital contendo uma série de medidas reguladoras dos espetáculos. ${ }^{59}$ Veremos mais à frente que tais providências não foram suficientes para disciplinar o público.

55 Vide BASILE, Marcello Otávio Neri de Campos. O Império em construção, p.279-280

56 Cf. O Regenerador do Brasil, n 1, 28/9/1831.

57 Todas as citações até aqui são da Astréa, $n^{\circ} 746,17 / 9 / 1831$

58 A Voz da Razão, n 3, 21/9/1831

59 As resoluções tomadas revelam bem o que costumava se passar nesses espetáculos. Doravante, nenhuma peça poderia ser encenada sem licença do juiz inspetor do teatro (multa de $30 \$ 000$ réis e oito dias de cadeia); os atores que alterassem os textos ou apresentassem "atitudes desonestas, e obscenas, ofensivas da moral pública" seriam multados entre $10 \$ 000$ e $20 \$ 000$ réis, e presos de quatro a oito dias; nenhum espectador poderia se manifestar em voz alta ou com gritos a qualquer outra pessoa da platéia ou do palco, sendo apenas permitido gritar para os atores bravo, caput e fora, assim mesmo podendo o juiz impor silêncio (multa de $6 \$ 000$ a $10 \$ 000$ réis e dois a seis dias de cadeia); ninguém poderia declamar ou recitar qualquer peça nas dependências do teatro, nem distribuir escritos não-impressos sem que tivesse entregado uma cópia assinada pelo responsável ao juiz inspetor e deste recebido visto (multa de $10 \$ 000$ a $20 \$ 000$ réis e seis a oito dias de prisão); ninguém poderia assistir os espetáculos sem estar "decentemente" calçado e vestido de casaca, sobrecasaca ou farda (multa de $6 \$ 000$ réis e três dias de prisão para os infratores e metade das penas para os porteiros que permitissem indevidamente a entrada); nenhuma pessoa poderia entrar bêbada e, se conseguisse, seria expulsa e colocada sob custódia até passar a embriaguez; qualquer um que jogasse moedas, pedras, laranjada ou qualquer outro objeto para dentro 
No ano seguinte, o aniversário da Constituição transcorreu em meio a fortes boatos, espalhados dias antes, de que seria sacudido por um "movimento popular". ${ }^{60}$ Nada terrível aconteceu, mas, nove dias depois, uma revolta exaltada, capitaneada pelo major Miguel de Frias e Vasconcellos, pareceu confirmar os temores. Até porque, tão logo foi debelada, surgiram novos rumores de que outra sedição estava prestes a estourar, desta vez promovida pelos caramurus. ${ }^{61}$ Assim, havia na Corte um clima de grande tensão e expectativa cercando as comemorações do tão aguardado primeiro aniversário da Revolução do 7 de Abril. Durante todo o dia, circularam rumores de rompimento da "facção frenética", que, todavia, também não se concretizaram. ${ }^{62}$ Ao menos até o dia 17, quando a cidade assistiu a um levante protagonizado pelo barão de Bulow.

Cinco meses depois, com os moderados abalados pela queda de Feijó do ministério e os caramurus (e parte dos exaltados) satisfeitos com a composição do novo gabinete, os festejos pelos dez anos da Independência não foram precedidos ou acompanhados de grandes temores. Mas nem por isso deixaram de ser marcados por afrontas à Regência e aos moderados. Uma deputação caramuru - da qual faziam parte Luiz Antonio da Silva (redator d'A Trombeta), José de Oliveira Porto Seguro e José dos Cacos (pouco depois, os três participariam dos distúrbios de 12 e 25 de setembro, em protesto contra a queda do ministério Hollanda Cavalcanti) — entregou uma coroa cívica ao tutor imperial José Bonifacio, após discurso de Porto Seguro exaltando-o como patriarca da Independência. À noite, o mesmo grupo saiu pelas ruas proferindo diversos "vivas anárquicos", repetidos depois no espetáculo teatral que então se realizava, juntamente com "versos anárquicos e sediciosos" recitados em homenagem ao tutor e em repúdio à Câmara dos Deputados (que, no final de julho, aprovara a destituição de José Bonifacio, rejeitada em seguida pelo Senado); tudo sem que os manifestantes fossem advertidos pelo juiz de paz do Sacramento, João José Moreira, responsável também pela vigilância do Teatro Constitucional Fluminense, localizado naquela freguesia. ${ }^{63}$ Da parte de alguns exaltados (da ala favorável à aliança estratégica com os caramurus), vivas foram dados ao Mártir da Pátria - Cipriano Barata - e uma banda de música, acompanhada da "Mocidade liberal Fluminense" e de grande número de "anciães respeitáveis", dirigiu-se às casas dos novos ministros e do tutor, tocando o Hino Nacional..$^{64}$

ou fora da sala de espetáculo seria preso por oito dias (trinta se reincidente). LEGISLATIVO MUNICIPAL. Editaes Camara Municipal. 1830-1842. A. G. C. R. J. Códice n 16-4-24 (p.26-26v).

60 Aurora Fluminense, $\mathrm{n}^{\circ} 610,28 / 3 / 1832$.

61 Sobre esses boatos e as revoltas que se seguiram, ver BASILE, Marcello Otávio Neri de Campos. O Império em construção, seção 2 do capítulo X (p.308-320) e capítulo XIII (p.388-414).

62 Cf. Aurora Fluminense, $n^{\circ} 615,11 / 4 / 1832$

63 O Independente, $n^{\circ} 110,12 / 9 / 1832$.

64 O Clarim da Liberdade, n $24,19 / 9 / 1832$.

\section{0}


Parece que acontecimentos como esse, que contrariavam a imagem idealizada dos festejos, nem sempre eram noticiados pela imprensa moderada (que era, de longe, a mais dedicada a cobrir esses eventos); a não ser para atacar os perturbadores da ordem. O mesmo incidente não foi relatado pela Aurora Fluminense, que, interessada em destacar a magnitude das comemorações, limitou-se a dizer que "alguns agitadores procuram azedar os ânimos e enfurecer irmãos contra irmãos", preferindo antes apelar ao já recorrente jargão de que o "povo Brasileiro é naturalmente dócil, e de costumes brandos". ${ }^{65}$ A postura parcial foi censurada por um correspondente anônimo do jornal — assinado O Girante - , que questionou se foram assim tão pouco notáveis os "gritos e vozerias" promovidos nas ruas e no teatro pelos intitulados "representantes da opinião pública" (os caramurus), os vivas dados aos Andrada e os morras a seus desafetos, e a homenagem ao recentemente alcunhado herói da Independência, prestada por uma comitiva que era "amálgama monstruoso de alguns festeiros das garrafadas de Março, de heróis das ceias de camarão em 1822 e de vários curiosos". Por fim, dirigindo-se ao redator do jornal (Evaristo da Veiga), o missivista dizia que chamava sua atenção para "despertá-lo, na sua inércia e sono que já enfada a quem deseja saber todos estes fatos imortais de que o Rio de Janeiro tem ultimamente sido teatro". ${ }^{66}$

Embora não fosse dada resposta, a bronca parece ter surtido algum efeito. Já no próximo festejo - o 2 de Dezembro - , a Aurora Fluminense informou (sem abandonar a linha ufanista) que os caramurus tentaram "desluzir o brilho" daquele dia, ao procurar intrigar e ridicularizar a cerimônia de revista da Guarda Nacional, espalhando notícias de que a ocasião seria aproveitada para "se proclamarem ditaduras e repúblicas"; além disso, diziam aos guardas que o governo iria então reuni-los para que os municipais permanentes os desarmassem. ${ }^{67}$

No ano seguinte (1833), o 25 de Março foi comemorado sem sobressaltos. Os caramurus permaneceram em casa ou compareceram quietos e em pequeno número ao Te Deum da igreja de São Francisco de Paula; o que poderia parecer provocação (a Sociedade Defensora organizava a cerimônia), não acarretou problemas, sendo-lhes "respeitado o direito do cidadão, o preceito da civilidade". ${ }^{68}$ Mas, por outro lado, poucos dias antes, a 13 de março, os caramurus aproveitaram para promover uma festividade - de caráter cívico para eles - bem particular e polêmica: o aniversário de dois anos das Noites das Garrafadas, celebrado em plena igreja de Santa

65 Aurora Fluminense, $n^{\circ} 673,10 / 9 / 1832$

66 Aurora Fluminense, $\mathrm{n}^{\circ} 675,14 / 9 / 1832$

67 Aurora Fluminense, $n^{\circ} 706,5 / 12 / 1832$

68 Aurora Fluminense, n 750, 27/3/1833. Ver também O Independente, nº 160, 27/3/1833. 
Rita, com a presença de quase cem praças da Guarda Nacional e do juiz de paz José Rodrigues Ferreira. ${ }^{69}$

As celebrações do 7 de Abril revelaram outra face dos festejos: o descaso ou a recusa em participar, bem como a vigilância e a delação dos não-patriotas. É o que denuncia O Rebeca de Barbeiro, missivista indignado d'O Sete d'Abril, que notou, na praia de Botafogo, que "poucas luminárias apareceram no aniversário da redenção da Nacionalidade Brasileira": só dez ou onze casas foram então iluminadas, das quais reconhecera, com espanto, que quatro eram de brasileiros adotivos e uma do genro do marquês de Barbacena. Já entre as mais gradas que permaneceram às escuras identificou as propriedades de J. F. Lopes, de um indivíduo conhecido como Pia Suja (provavelmente padre), do visconde de Cachoeira, da marquesa de Nazareth e, para sua maior surpresa, do então deputado Araujo Lima (que em 1837 se tornaria regente), todos caramurus. ${ }^{70}$

No mesmo dia, só que na concorrida iluminação da Villa Real da Praia Grande, vivas, saídos do meio do povo, foram dados a Pedro II, à liberdade e à Constituição, mas "não quiseram nada com a Regência".$^{71} \mathrm{O}$ silêncio do público acerca de certos vivas convencionais (quase obrigatórios) era uma forma sutil de resistência - diferentemente dos agressivos morras - ao objeto em questão. O evento parece ter sido bem freqüentado pelos exaltados, pois poesias foram ali recitadas conclamando-os a outra revolução para derrubar os novos tiranos da Regência:

Nossa Pátria escravizada, Brasileiros, não deixemos, De novo se empunhe a espada Ao Campo da honra voemos.
[...] Que enquanto a gente Exaltada Sangue nas veias correr, Não hão de os tiranos ver Nossa Pátria escravizada. ${ }^{72}$

Por sua vez, O Sete d'Abril — futuro arauto do Regresso que ainda se dizia moderado, mas em dissidência a Feijó e Evaristo - reclamava das homenagens que vinham sendo prestadas nesses eventos. Em 1831, espadas de honra foram dadas a "indivíduos que mal as mereciam"; no 7 de Abril de 1832, a Sociedade Defensora ofereceu uma coroa cívica ao então ministro da Guerra (Manoel da Fonseca Lima); no 7 de Setembro deste ano, o mesmo foi entregue a José Bonifacio; e agora, no 7 de Abril de 1833, o agraciado foi Evaristo da Veiga. "Dando-se coroas cívicas, e bailando se têm passado 2 anos de revolução; tempo perdido", concluía o jornal. ${ }^{73}$

69 O Sete d'Abril, $n^{\circ} 24,19 / 3 / 1833$

70 O Sete d'Abril, n' $\mathrm{n}^{\circ} 33,20 / 4 / 1833$

71 O Brazil Afflicto, $\mathrm{n}^{\circ} 1,20 / 4 / 1833$

72 Ibidem, no $3-9 / 5 / 1833$

73 O Sete d'Abril, $n^{\circ} 31,13 / 4 / 1833$

\section{2}


Meses depois, na comemoração do aniversário da Independência, após os vivas nacionais, rompeu uma voz no teatro, tributando-os ao Patriarca da Independência, que foi respondida com reiterados gritos de Viva o Patriota Feijó, da mesma forma em que os vivas à Constituição jurada foram abafados por diversos brados em favor da Constituição com as reformas legais; vendo assim que não tinham espaço, caramurus que aguardavam em grupo do lado de fora do teatro para aplaudir o tutor e insultar os liberais decidiram bater em retirada. ${ }^{74}$ Mas o protesto se repetiu, no mesmo teatro, na noite do 2 de Dezembro; após os vivas ao imperador e aos "objetos de nosso culto político", ergueram-se alguns vivas a José Bonifacio, prontamente respondidos por outros ao senador Feijó. ${ }^{75} \mathrm{~A}$ despeito das tentativas de enquadramento, o teatro continuava a ser um "termômetro da Opinião Pública", como notou Marco Morel, onde se manifestavam opiniões diversas e conflitantes. ${ }^{76} \mathrm{O}$ mais grave, porém, iria acontecer após o espetáculo, quando correram falsos boatos de que a Sociedade Militar estaria exibindo em sua sede, ali ao lado, no largo de São Francisco de Paula, um painel luminoso com a figura de dom Pedro I, em comemoração ao 2 de Dezembro; foi o bastante para que as pessoas ali reunidas se juntassem a outras e se dirigissem àquele local, promovendo um grande quebra-quebra nas instalações da agremiação caramuru. ${ }^{77}$

Observa-se, portanto, que, tal como a imprensa, as associações e as revoltas, as festas cívicas regenciais também eram arenas de disputas políticas, que, por trás da pretensa unidade e harmonia, reproduziam as divisões e os conflitos entre moderados, exaltados e caramurus. Para além da luta pelo controle simbólico do espaço público, estava em jogo a construção de uma memória nacional acerca dos objetos alçados ao panteão cívico da pátria - a Constituição, a Abdicação, a Independência e o imperador Pedro II - eles próprios eivados de controvérsias.

\footnotetext{
74 Aurora Fluminense, no $814,11 / 9 / 1833$

75 Aurora Fluminense, $n^{\circ}$ 850, 6/12/1833. Por essas e outras, o redator d'O Exaltado, Marcelino Pinto Ribeiro Duarte recomendava a seus patrícios e amigos: "nada de Vivas, e de Versos em vossas reuniões"; tais práticas, dizia facilitavam a qualquer intrigante "introduzir um — viva — odioso no meio das aclamações de um Povo entusiasta", o que acabaria sendo utilizado contra a oposição. O Exaltado, $n^{\circ} 31,7 / 11 / 1832$.

76 MOREL, Marco. La formation de l'espace publique moderne a Rio de Janeiro, v.ll, p.355-356. Testemunha do incidente no teatro naquele 2 de Dezembro, o embaixador francês no Brasil, conde de Saint-Priest, relatou, em correspondência ao Ministério dos Negócios Estrangeiros da França, que os membros presentes da Sociedade Defensora deram vivas durante todo o espetáculo (assistido por Pedro II) ao imperador e à Regência, seguidos de gritos de abaixo o tutor; quando alguém da platéia, em provocação, resolveu contrariar essas evocações, formouse um grande tumulto, a ponto de suscitar a intervenção do ministro da Justiça, que teve de tomar a palavra em pleno teatro para pedir calma. Cf. MOREL, Marco. La formation de l'espace publique moderne a Rio de Janeiro, v.ll, p.360

77 Vide BASILE, Marcello Otávio Neri de Campos. O Império em construção, p.441-443.
} 


\section{Regresso patriótico}

Mas, tal como aqueles outros espaços de sociabilidade política, as festas cívicas regenciais - tomadas no âmbito da politização que fundamentalmente as revestia - começaram a declinar progressivamente, na Corte, a partir de 1834, conforme se enfraqueciam e logo saíam de cena caramurus, exaltados e, por fim, moderados, em meio ao novo arranjo político operado pelo Regresso. Ainda que de modo oposto a seus ideais, essas festas eram em grande parte alimentadas pelas disputas entre facções e pelas tentativas, em especial dos moderados, de se afirmar sobre as demais, mediante a promoção dos festejos. Pode-se cogitar também que, paralelamente à retração dos mecanismos de ação política, o entusiasmo cívico arrefeceu entre a própria população.

O fenômeno foi notado pela mesma imprensa que apoiava as celebrações. Por ocasião do 25 de Março de 1834, O Sete d'Abril comentava: "Até 1833 deu-se graças a Deus pelo juramento da Constituição, em 1824: este ano de 1834 até poucas luminárias houve. No fim de outra década... Advinhem". ${ }^{78}$ Passados apenas dois anos, o missivista O Athaide Chia, do mesmo jornal laconicamente observou: "Tudo acaba! Nem festa... nem baile... nem iluminações!... Murcho e chocho Cortejo e algumas luminárias: eis aí todo o culto rendido ao DIA 25 DE MARÇO!"79

Para o declínio das festas na Corte contribuiu também o fato de que pelo menos dois dos quatro objetos celebrados foram perdendo parte substantiva de seus significados e, logo, de sua razão de ser. A sagrada Constituição jurada foi maculada pelo Ato Adicional, que alterou consideravelmente um de seus principais dispositivos, a centralização; e, sem os caramurus, ficou órfã de seus grandes defensores. Por sua vez, as realizações da gloriosa Revolução do 7 de Abril foram impiedosamente atacadas pelo Regresso, que, vitorioso sobre os dois grupos que promoveram o movimento - moderados e exaltados - , as fez regredir ao antigo estado de coisas. Já a Independência e Pedro II não sofreram esses reveses, permanecendo firmes no rol cívico da nação; mas não deixaram de ser afetados pelo processo de retração do espaço público na Corte. ${ }^{80}$

Analisando as comemorações do 7 de Setembro na Capital do Império entre 1823 e 1864, Hendrik Kraay também constatou um arrefecimento desses festejos a partir de 1834, com a redução de sua politização, tornando-se um festival mais rotineiro e aparentemente consensual; seriam revigorados somente na segunda metade da década de 1850 (desta vez, estimulados

78 O Sete d'Abril no $135,12 / 4 / 1834$

79 Ibidem, n 331, 26/3/1836.

80 Ao comentar o 7 de Setembro, em 1835, a Aurora Fluminense ( $\left.n^{\circ} 1092,9 / 9 / 1835\right)$, que tanto destaque deu às festas cívicas, limitou-se a falar da importância daquele evento, sem mencionar os festejos realizados.

\section{4}


por associações patrióticas a isso destinadas), esmorecendo de novo no início da década seguinte. ${ }^{81}$

O fenômeno não foi exclusivo do Rio de Janeiro, embora não se possa afirmar que fosse comum a todo o Império. Na Bahia, Kraay demonstra a permanência da força do 2 de Julho no Segundo Reinado, quando continuou a ser alvo de disputa da elite política baiana; mas seu êxito, segundo o autor, deve-se ao fato de estar associado à localidade - à experiência de luta e ao patriotismo local..$^{82}$ Em Minas Gerais, o memorialista Francisco de Paula Rezende, que registrou o regozijo público dos rituais cívicos da Regência, recordava que, após a revolta mineira de 1842, já não havia mais aquelas "grandes e tão pomposas festas que em outros tempos se faziam". ${ }^{83} \mathrm{O}$ testemunho é corroborado pelo estudo de Carla Chamon, que verificou um declínio dos festejos realizados na província já a partir do Regresso. ${ }^{84}$ Mais tarde, no Maranhão, o Jornal de Timon, de João Francisco Lisboa, notava, em 1852, que "os grandes dias nacionais ou provinciais já não são popularmente festejados"; a explicação era simples: a não ser falta de recursos, era "resfriamento do patriotismo", visto que "o verdadeiro patriotismo só se acenda em face dos perigos". ${ }^{5}$

Talvez a explicação tenha alguma validade também para a Corte. Uma vez eliminadas as ameaças da anarquia republicana e do despotismo restaurador, representadas por exaltados e caramurus, e sufocadas todas as revoltas promovidas por esses grupos; e uma vez satisfeitos, dentro de certos limites, os desejos de reforma constitucional, com o Ato Adicional, o fogo do patriotismo foi aos poucos se apagando na Capital do Império, paralelamente ao avanço do Regresso. Perigos continuavam existindo, pondo em risco a integridade nacional, mas estavam agora distantes, deslocados para províncias mais afastadas. Na Corte, a ordem voltava a imperar.

81 O autor alerta, no entanto, para os recorrentes julgamentos de contemporâneos, ao longo do século XIX, referentes à alegada morte do 7 de Setembro. KRAAY, Hendrik. Sete de Setembro: changing meanings of Independence celebrations in Rio de Janeiro, p.1-2; 11-20. A popularidade do 7 de Setembro na Corte, na década de 1850 (obscurecida pela Guerra do Paraguai, que teria liquidado o patriotismo brasileiro) foi testemunhada por MORAES FILHO, Alexandre José de Mello. Festas e tradições populares no Brasil. Belo Horizonte: Itatiaia /São Paulo: EDUSP, 1979, p.96-100.

82 KRAAY, Hendrik. Between Brazil and Bahia: celebrating Dois de Julho in nineteenth-century Salvador, p.260-264; KRAAY, Hendrik. Definindo nação e Estado: rituais cívicos na Bahia pós-Independência (1823-1850), p.73-84. Após a proclamação da República, o 2 de Julho manteve-se popular, incorporando novos significados aos já existentes (como a associação da figura central do caboclo nessas festas não só às raízes indígenas da nacionalidade brasileira, como tradicionalmente, mas também à cultura afro-brasileira, manifesta no candomblé). Cf. ALBUQUERQUE, Wlamyra Ribeiro de. Algazarra nas ruas: comemorações da Independência na Bahia (1889-1923). Campinas: Editora da UNICAMP, 1999

83 REZENDE, Francisco de Paula Ferreira de. Minhas recordações, p.214

84 CHAMON, Carla Simone. Festejos imperiais: festas cívicas em Minas Gerais (1815-1845), p.21.

85 LISBOA, João Francisco. Jornal de Timon: partidos e eleições no Maranhão. Org. José Murilo de Carvalho. São Paulo: Companhia das Letras, 1995, p.189. 
As festas cívicas regenciais eram, portanto, produto de uma seleção dos acontecimentos da história pátria, considerados dignos de figurar no panteão nacional, sobre os quais eram feitas determinadas leituras, periodicamente recordadas, fixadas e difundidas através dos rituais que marcavam as comemorações e também dos relatos controversos feitos na imprensa. Não obstante os conflitos e as ações dissonantes acerca dos ideais preconizados, e malgrado as controvérsias sobre os próprios objetos celebrados, as festas desempenharam a função pedagógica de promover a afirmação dos valores nacionais. Os antagonismos exprimiam as disputas políticas entre as facções e diferentes noções a respeito dos símbolos nacionais, que remetiam a compreensões distintas sobre o processo de formação da nação brasileira. Mas jamais se colocavam em questão a lealdade ao Estado (embora nem sempre ao governo) e principalmente o compromisso com a nação, que, ao fim e ao cabo, todos aspiravam construir e da qual todos já se sentiam membros. Neste sentido, as festas cívicas foram um dos eixos de construção - de baixo para cima, como de cima para baixo — de uma tosca identidade nacional. Foram, assim, um mecanismo de interação entre o poder e as diversas camadas sociais, constituindo um lugar de exercício da cidadania e contribuindo para fomentar o espírito público. Jamais saíram de cena, mas, paradoxalmente, perderam força quando o Regresso começava a estabelecer, na Corte, um relativo consenso. 